\title{
Engaging with the book of Ruth as single, African Christian women: One African woman's reflection
}

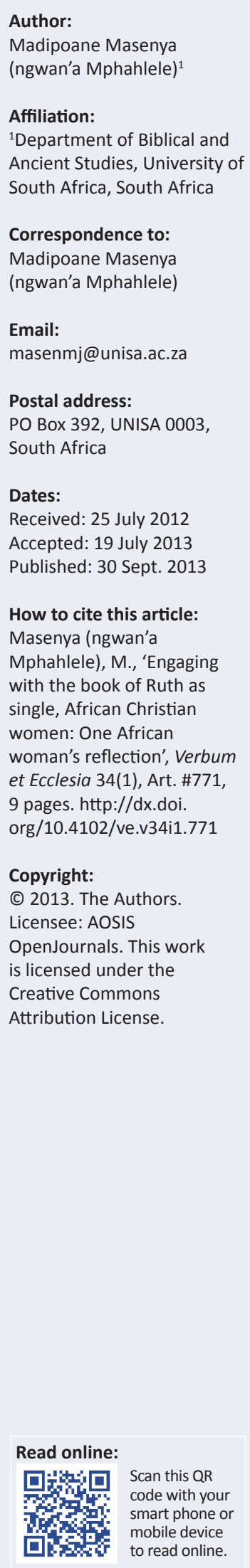

In their quest for knowledge, biblical scholars make the Christian Bible the object of scrutiny, analysis and critique. However, in the African-South African context dealt with in this article, the Bible is accessed not only for knowledge, but mainly for nurturing faith and for life. Hence, the character of Ruth in the Hebrew Bible is still viewed by some widows as providing a model of courage and steadfastness in a context in which heterosexual unions remain a norm. As the book of Ruth portrays some points of resemblance between the cultural milieu that produced it and many African contexts, this article has also benefited by investigating the kind of reading which might emerge if the book is read from the perspective of traditional African women. Questions addressed by this article were: which prospects may the story have if read in a traditional African female setting? Are there any prospects for knowledge, for belief and for life if the book is read from the perspective of single African Christian women in South Africa, women for whom the Bible remains important for their spiritual nurturing? If there are prospects, are these really knowledge-worthy, faith-nurturing and life-enhancing?

\section{Introduction}

Whilst growing up, my siblings and I had the opportunity to travel to Moletjie, a village in the Limpopo Province, to visit our grandmother. During certain evenings, we would have the opportunity to sit around the fireplace and listen to grandma relate stories to us. Although I may not be as skilled as Mokgekolo wa Moletjie, ke ra makgolo Mmakgabo, that is Mmakgabo, my grandmother, in the art of story-telling, I thought the readership could benefit from a presentation of a narrative of one African woman whose praise-name is Moremadi. Hers is the narrative of Ruth's tale in the Hebrew Bible. The story serves as a background to a Bible study on the book of Ruth.

\section{Reading the book of Ruth in Africa: Moremadi's story Ruth 1}

Long, long ago, a man called Elimelech decided to leave gae, literally, home. The word gae designates a place in Africa where one is regarded as ngwana wa mobu [child of the soil]. Thus according to the narrator, Elimelech left his ancestors' land and headed to Moab because of famine in the land. ${ }^{1}$ Moremadi suddenly remembers though, that historically, there is no evidence to support the claim that there was famine in the land. That notwithstanding, Elimelech's move makes sense to Moremadi as she remembers that tlala e ntšhitše noga moleteng [hunger forced the snake out of its hole]. In the midst of undesirable circumstances, one, of necessity, has to leave one's comfort zone; even snakes, according to the wisdom of African peoples, have to leave the comfort of their abode when hunger strikes. Elimelech's difficult move thus makes sense to Moremadi. The narrator's claim that there was famine in the land (Rt 1:1), reveals something of the link between Elimelech's people and the land. Later, when the Sacred Other would be portrayed as having visited his people (Rt 1:6), Moremadi would not be surprised that Ruth and Naomi would be portrayed as arriving in Bethlehem at the beginning of the harvest, a signal for Moremadi that sooner than later, the people would come and enjoy the provisions of the land (Rt 1:22). However, as has been the case in Africa, those who had access to more land (cf. Boaz) were basically a male minority, vis-à-vis the many (both male and female) who did not possess the land (cf. the many reapers in Boaz' field; Rt 2:4-7). From the narrative of Ruth, the aforementioned minority also appeared to have had legitimate authority on land allocation (cf. Rt 4:3ff.). The visitation by death in Elimelech's house makes Moremadi wonder whether there

1.Moremadi, though, notices some points of resemblance and dissonance between the cultural contexts which produced biblical texts and the African contexts. During the patriarchal period for example, a place called gae would not have been in the vocabulary of the Israelite ancestors as they were wanderers. The situation would have differed with the period of settlement and, in particular, during the monarchic period where there was more stability and the understanding that a long-held dream for a promised land (read gae or home) would have been realised. However, the displacement by 'exile' would have removed the significant number of the Israelites from gae and their return during the Persian period would have reconnected them with home (gae). The observation that the psalmist (cf. Ps 137:4) could be captured as wondering how they could chant a song to the Lord in a foreign land (a land that is not gae, in which they were not legitimate 'children of the soil'), in the view of Moremadi, reveals something of a point of resemblance between the two contexts in terms of a place called gae (home). 
could have been a family (or families) bewitching Elimelech's household. Perhaps the Sacred Other and the ancestors had turned their backs against his household because, in Africa, such calamities could not just have occurred!

As mmago ngwana a swara thipa ka bogaleng [a mother holds the knife by its cutting edge $]^{3}$, Naomi's concern about her daughters-in-law's marriages makes sense (Rt 1:6-13) because of Naomi's age and the fact that there was no more family in Moab. In a way, Naomi exhorted them to divorce the grave (of their husbands)! In Moremadi's culture though, lebitla ga le hlalwe, the (male) grave cannot be divorced. The tenor of the preceding proverb reveals that for a Northern Sotho-Pedi woman, once married, ever married. What Ruth does, by clinging to her mother-in-law even after the death of her husband, makes perfect sense to Moremadi. On the one hand, Ruth's words of commitment to Naomi (cf. Rt 1:15-17) amaze her as they sound like those addressed by a wife-to-be to a husband-to-be. However, in the verilocal African context, where a woman is married both to a man and his family (cf. also within the Israelite communal context), where a grave cannot be divorced, Ruth's words of commitment to Naomi occasion no surprise. Moremadi can thus not understand why Naomi was not impressed by Ruth's decision to ascertain that, despite Mahlon's death, she would still stay with his family. Naomi's bitterness is revealed from her encounter with Bethlehem's women. Moremadi marvels that the same African mentality of putting blame for human calamities on the supernatural is also displayed by Naomi (cf. Rt 1:20-21). ${ }^{4}$ Lehutšo le ka ka legonono ${ }^{5}$ [the wish is just like the suspicion] is the proverb which comes to her mind when she learns that the two women's arrival in Bethlehem coincides with the beginning of barley harvest (Rt 1:22).

\section{Ruth 2}

In a patrilocal African context, the family which usually gets more attention is a husband's; hence, lebitla la mosadi ke bogadi, ${ }^{6}$ a married woman's grave is (located at) her husband's village. Moremadi is thus not surprised when Boaz is introduced as

2.The cause and effect mentality typical in biblical Israel (cf. in particular, the optimistic wisdom underlying the book of Proverbs, as well as the Deuteronomistic history) and many an African (Northern Sotho-Pedi) proverb, reveals something of such a notion. Eliphaz, informed by such a mentality questioned Job: 'Think now, who that was innocent ever perished? Or where were the upright cut off? As I have seen, those who plow iniquity and sow trouble reap the same. By the breath of God they perish, and by the blast of his anger they are consumed' (tob 4:7-9, New Revised perish, and by the blast of his anger they are consumed (Job 4.7-9, New Revised order within the supernatural realm was believed to have been disturbed.

3.A mother is believed (and expected) within the Northern Sotho-Pedi culture to be the one who ensures a successful management of the household, particularly as it pertains to children's welfare.

4. Refer to Footnote 2 on the cause and effect mentality which typified both biblical Israel and African societies.

5.This expression is usually said in a desperate situation when the speaker expects and/or wishes that something positive would happen. Yes, something good is most probably likely to be experienced by Naomi and Ruth as they arrive in Bethlehem not during a time of famine, but at the onset of barley harvest.

6.The proverb reveals that once a woman is married, she has to make sure that she stays with her in-laws until death; hence, her grave of necessity should be located at bogadi, that is, her husband's place. Although there is a vast gap between the african context in which Moremadi resides and the world of the production of the story of Ruth, Moremadi notices that the graves of the matriarchs (cf. Sarah the story of Ruth, Moremadi notices that the graves of the matriarchs (cf. Sarah and Rachel, Gn 23:1-16; 35:16-21) were not in their places of or
fathers' households, but at the places selected by their husbands.
Elimelech's kinsman. ${ }^{7}$ She notes another connection between the Judeans and the land when Ruth plans to go and glean. To her mind suddenly comes the proverb, tšhilo le lwala re tšere, le tlo šala le eja lewana [the pestle and the mortar we have taken away, you will only eat grits]. The tenor of the preceding proverb reveals that the family which gives out a daughter will experience hunger as a diligent girl, who will ensure that there is food in her husband's household, is married off. The recipient family celebrates as the bride marks the exit of hunger from the family. Moremadi then remembers a related saying familiar in the South African political history: wa thinta abafazi, wa thinta' imbokodo (tšhilo), o zu ku fa! Literally, if you strike women, you strike a (grinding stone, imbokoto or tšhilo) and you will die! She then remembers Nzimande's (2005) observation about imbokodo (tšhilo) in the traditional Zulu African contexts that:

Imbokodo was an important commodity in traditional Zulu African homesteads and villages, so often utilized on a day-today basis that it could not be loaned to neighbours ... Without imbokodo there is no food in a traditional African household. (p. 22)

That Naomi did not hesitate to consent to Ruth's request to glean reveals something of the joy of gaining a resourceful human being.

Modimo ga o lahle ngwana wa ona is an expression used to reveal that God cannot forsake God's child. ${ }^{8}$ The exaggerated hospitality which Ruth receives from Boaz, the man of substance (the ' $\imath ̌ s$ hayil), seems to bear witness to the saying. Could it be that the hospitality was evidence that Boaz was already drawn to Ruth on account of her attractiveness? Could Ruth have enjoyed the exaggerated hospitality on account of her relationship to Naomi, who was Boaz' nextof-kin? Could it be because of Boaz' kindness, hesed or botho? Could these all be confirming that 'one hand washes the other'? The latter appears to carry the sense of Boaz' words in Ruth 2:12:

May the LORD reward you for your deeds, and may you have a full reward from the LORD, the God of Israel, under whose wings you have come for refuge!

The 'coincidence' of Ruth gleaning in a next-of-kin's field, the mention of Boaz' relationship to Naomi, the 'exaggerated' botho which Ruth receives from Boaz and Naomi's blessing on Boaz, all confirm to Moremadi that people do experience various seasons, that is, both good and bad ones, is it not that matšatši ga a hlabe ka go swana [the suns do not rise in the same way]? Surely, Ruth and Naomi may well have said, Ngwaga o sa re ratego, seleganya! [Oh year, you (who) hates us, go away!] as the two women would have bidden

7.The word which is translated in the NRSV variously as 'kinsman', 'near kinsman' and 'next-of-kin' and in the New International Version (NIV) as 'kinsman-redeemer', is the Hebrew word go'el. The word refers to one who buys a relative's property so as to keep it in the family (cf. Lv 25:25), or one buying a relative out of slavery (e.g. Lv 25:48) (Tull 2003:65).

8.The expression is used to reveal the belief that the Sacred Other or God will, of necessity, intervene in the desperate situation of the weak.

9.The Hebrew word hesed, variously translated as 'kindness', 'loving kindness', 'faithfulness', or 'loyalty' (Rt 1:18; 2:20; 3:10), used both by God and persons, is one of the key concepts in the book of Ruth. In it, God uses a non-Israelite woman from Moab to achieve God's plan for the world (Rt 4:13-22) (Masenya [ngwan'a Mphahlele] 2004:89). 
farewell to a hostile year. Moremadi ruminates that it seems as if the two are in for a patriarchal, yet delicious treat! Moremadi marvels that Ruth, a mohedene ${ }^{10}$, has actually served as a model of unconditional love and kindness to the counterpart of bahedene, that is majakane (read, Naomi and Boaz)! Although Dube (2001:179-195) may argue differently regarding what she perceives to be an unhealthy relationship of interdependence between the two countries, Moremadi thinks that from Moab (cf. Ruth), Judah (cf. Boaz and Naomi) has more to learn.

\section{Ruth 3}

As she ponders on Naomi's keen desire to secure a bright future for her daughter-in-law, Moremadi is fascinated by the comment by Tull (2003) that Naomi lacked seeds:

Naomi's problem is the lack of seed of every kind: lack of grain, lack of offspring and the lack of the means of producing offspring. Boaz's generosity toward Ruth in the giving of so many kinds of grain, described in so many ways, foreshadows his later role as giver of human seed. (p. 64)

The motherly concern for a daughter's security through heterosexual marriage, in a world which defined women through such a union, a world unlike ours with many an educated widow, persuades Naomi to revert to her earlier plan (cf. Rt 1:8-13). Did the ancestor not say: la go hlabela o le orele, ka moso le hlabela ba ba bangwe? [Once the sun has set on you, enjoy the benefits, tomorrow it will set on others]. ${ }^{11}$ Fertile soil seems to have been prepared for levirate marriage. Hence Naomi's advice that Ruth go and 'share a (traditional) mat' (a robale legogong) with Boaz. What is strange to Moremadi though, is that the legogo in question, would not be shared with Boaz' wife that night, but with a wife-to-be! (that is, if the text is read forwards), something undesirable in traditional African communities. Cibalonza (1998) writes:

... the woman is expected to be satisfied with playing a passive
role in it [married life]. Consequently, she is not expected to seek
sexual satisfaction for herself. It is rare in fact that a sexually
excited woman will dare directly invite her partner to copulation.
If she did this, she would be considered oversexed, likely to
misbehave, and inclined to adultery. (p. 40; see also Mbuy-Beya
1989a:49-55)

Equally strange would be an initiation of marriage by a daring young woman. Aware of forms of marriages such as seantlo [in the event of a wife's death], go hlatswa dirope [when there is barrenness], go kgobelwa [levirate] and go nyalwa ke lapa [marriage by a family], Moremadi can resonate with Naomi's planned intervention regarding Ruth's future marriage. What she finds problematic and scary, given the pronounced violence against women in South Africa, is the apparent desperateness of two women who seem to have decided that female bodies could be used for security through marriage.

10.'Mohedene' [heathen] is a name which was historically given to those Africans in South Africa who refused to accept Christianity in favour of African traditional religions. Its plural counterpart, 'majakane' referred to those who went to church or affiliated with Christianity. In my view, going to church though does not necessarily categorise church attendants or affiliates as followers of Christ, that is, as Christians.

11.The preceding saying encourages people to enjoy life as long as it offers prosperity and other benefits. In the future, such benefits might be withdrawn from them to be enjoyed by others.
Moremadi is equally surprised that Boaz, a man of substance, endorses the two women's 'shady' deal! However, given the age old trend of older men preferring younger women (as in the song: ba mpha monyana ka rata, ba re mo tlogele ka gana; ba mpha mosadi ka gana, ba re mo tlogele ka rata - they offered me a young woman I liked it, they told me to leave her, I refused; they gave me a woman, I refused, they told me to leave her, I liked that), Moremadi seems to get the picture. She suddenly remembers Kanyoro's (2002) words:

African women notice the age difference in the marriage between Boaz and Ruth. The age margin between Ruth and Boaz is an issue of concern when related to child marriages and sexual abuse of women by men in power. How about when such a biblical story is used as a justification also for African families who marry their young girls to old men? Thus these questions generated by the life experience of African women, pose a dilemma for basing liberation theology on cultural practices that have the potential for denying women possibilities for 'abundant life'. (p. 37; see also Jn 10:10)

Boaz's words of affirmation make sense:

May you be blessed by the LORD, my daughter; this last instance of your loyalty is better than the first; you have not gone after young men, whether poor or rich. (Rt 3:10)

From Boaz' words, it is evident that Ruth's proposal for marriage and Naomi's desire for her marriage were to be realised. Ruth o tla kgobelwa a next-of-kin who was closer to Mahlon than was Boaz. However, if the former, would not be keen to redeem Ruth, Boaz would. Moremadi notes another connection between the characters and the land (haaretz). The latter, would serve as a (natural) legogo [traditional mat] to enable Ruth to uncover Boaz' feet. The night's cover (darkness) would provide a convenient atmosphere in which Ruth would propose to Boaz without fear of being seen and heard. Dawn would set in to enable Ruth to slip away and be '... up before one person could recognize another ...' (Rt 3:14). Why has Boaz been so concerned about the welfare of Naomi's family? Moremadi wonders. Perhaps Boaz did not have any sons from previous marriages? Perhaps such a commitment revealed something of Boaz' hesed (botho), a man who was willing to sacrifice his 'single' status for a woman who came from a notorious country? Moremadi cannot but speculate. Boaz gives Ruth six measures of barley. Such 'gifts', which usually accompany nocturnal female 'offers' to men in present day South Africa, make Moremadi wonder for how long female bodies would continue to be violated. Phiri's (2006) words come to her mind:

The fact that Ruth could have been mistaken for a prostitute had she been discovered by other men at the threshing floor raises the problem of prostitution in Africa. The poverty that the majority of Africans live with has forced many girls and women into prostitution. This is an issue that the church cannot just wish away. Serious reflection that leads to action is required because of the dangers to which prostitutes expose themselves. Any effective way of dealing with this issue must also take account of the clients who keep the trade going. (p. 322, author's own emphasis; cf. also Mbuy-Beya 1989a:49-55)

Naomi's (implied) positive response to such 'gifts' (Rt 3:18) can, for example, not be helpful in the struggle against gender and socio-economic injustices and, in particular, the trafficking of female bodies, Moremadi ponders. 


\section{Ruth 4}

Sooner rather than later, Ruth would be allocated (go kgobelwa) a next-of-kin from Mahlon's family. In Moremadi's culture, such a next-of-kin, was or is most likely the deceased's younger brother. That a debate could ensue about exactly who could be allocated to Ruth at the kgoro [city] gate is unfamiliar to Moremadi. ${ }^{12}$ She wonders whether to blame the next-of-kin for refusing to redeem Ruth or whether to praise him (Rt 4:6) for refusing an 'imposed' kind of marriage.

Babies, babies, babies! Men, outsiders to female reproductive anatomy, are preoccupied with procreation and male lineage! Moremadi marvels. Even before the marriage could occur (cf. Rt 4:13), the well wishes are conspicuous about their silence on the conjugal life of the 'bride' and 'groom', quiet about the economic benefits which the two widows would gain from the union. Instead, they are loud about female reproductive capacities and male lineage (Rt $4: 11,18)$. It is wished that a mohedene would be able to build the house of Israel (Rt 4:11, 17; cf. also the genealogy in Rt 4:18-22). The obsession with progeny is reinforced by Moremadi's observation that in just one verse, Ruth and Boaz are portrayed as married, living together, having sex, Ruth conceiving and delivering a baby! She is aware of the obsession with (male) children, prevalent in African cultures and quickly remembers the Akan saying: 'Ena yie' ['motherhood is supreme'] (Masenya [ngwan'a Mphahlele] 1996:166) and, 'A ba tswalwe ba ate gobane mo-nale-pelo ga a tsebjwe' ['Let them be birthed and let them increase for the one with a long heart is not known'].

She then notes a shift from the male preoccupation with female reproductive powers to the women's celebration of the fruit of one woman's labour pains. The Bethlehem women assure Naomi that Obed would take care of her at her old age, just as his mother, chose to cling (davaq) to her, at a critical moment. Although Ruth is celebrated for who she has been to Naomi, she is not directly celebrated as an individual, Moremadi observes. That does not add up as, in Moremadi's context, Ruth, the mother, could have been showered with praise-names for not having returned from madiba [deep waters] empty-handed. Having been socialised within an African patriarchal, patrilineal setting, in which property is usually owned by men, Moremadi is intrigued by the women's claim that 'A son has been born to Naomi' (Rt 4:7).

At the end of the tale, she notices the following points of resemblance between the two worlds. In both worlds, the whole is religious: Yahweh, has a share in the economy as Yahweh is believed to bring food (Rt 1:8), to care for widows by providing relevant laws (cf. gleaning: Lv 19:9-10; 23:22;

12.Within an African traditional setting of levirate marriage, Ruth's request to a man who was not her deceased's husband's brother would not quite fit: the go'el, translated as 'next-of-kin' in some Bible translations, had no connections with marital obligations towards widows. Moremadi remembers Sakenveld's (1999:59) words in this regard. 'The term (goel) is a legal one, but it is highly charged socially words in this regard: The term (goel) is a legal one, but it is highly charged socially because it focuses on the preservation of family and community. And yet there is a glaring gap between the appearance of the word goel associated with rights or responsibilities pertaining to marriage. The regulation having to do with rights and responsibilities in cases where a man is to marry his brother's widow to perpetuat the family line is the law of levirate marriage ... but the levirate provisions contain no reference to the goel. Only in the Book of Ruth do the two spheres of marriage among kin and land redemption among kin come together.'
Dt 24:19-22). Religion and politics seem to be hand-in-glove as the city gate elders could pronounce the blessing of progeny on Boaz and Ruth (Rt 4:11). Naomi could blame Yahweh for deaths in her family (Rt 1:20-21) and see Yahweh's hand in providing a go'el (Rt 2:20). The proverb, letlalo la motho ga le bapolelwe fase [The skin of a human being cannot just be skinned on the ground], in Moremadi's context, reveals something of the belief that deaths cannot just happen, forces within the supernatural realm could be involved. One calamity after another may be accounted for, by the belief that the ancestors (and God) have turned their backs against the victims. ${ }^{13}$ For Naomi, just like for traditional Africans, the dead seems to have been alive (cf. Rt 1:8; 2:20). The concept of go' $\mathrm{el}$ and the preoccupation with the male lineage also points in the same direction.

In both cultures, heterosexual marriage is normative. Moyo (2005:58; author's own emphasis) remarks: 'Culturally, women have been socialised and schooled on how to please their male sexual partners so as to ensure that they remain married to them.' In such contexts, the plight of single women, particularly that of poor younger widows could apparently only be solved through marriage. Such a norm appears to ignore the situation of older widows and same-gender loving women, amongst others.

In both contexts, female anatomy is celebrated basically, for its capacity to bear male children. The reproductive capacities of younger widows are thus celebrated, a situation was created in which women who are married, are mothers and not wives. Women who are left 'to function as de facto lone wives, and single parents, women who are mothers without being wives' (Chandler 1991:2).

Having glimpsed Moremadi's story, our discussion will hopefully benefit by engaging the following questions: In a context where the book which contains the story, is not only read for knowledge, but also approached in faith for life, how may the story of Naomi, Ruth and Boaz be received? Are there any prospects for knowledge, for belief and for life if it is read from the perspectives of those women for whom the Bible remains important for spiritual nurturing? In particular, which possibilities would the story have if read by single African Christian women? In order to answer these questions, the audience will benefit by listening to the narratives of some of these women. ${ }^{14}$

13. Refer to Footnote 2 on the cause and effect mentality shared by both biblical Israel and African communities.

14.Within the context of action and participatory research, research in which the participants are actively involved with a view to solving a particular challenge (Hofstee 2006:127) (in our case, the sexual challenges facing women within Pentecostal church settings), a Bible study on the book of Ruth was conducted. It was conducted within the context of a group interview, in which the contributions of the participants (eight women in that setting) enriched each other and the researcher as well. It occurred within the sacred space (church) in which the group worships, that is, the Makweng International Assemblies of God church, Sovenga, Limpopo Province. The clergy persons were informed about the undertaking and the women's permission to use their views for the purposes of writing an academic paper, but also making their voices heard, was sought with success. After the discussions, the single women (both widows and those who either never tho who eithe never married or divorced) completed the questionnaires. Two other women (one widow who is also a member of the same church, who participated in a previous study on the same book, was interviewed telephonically). She also completed th questionnaire. The the Mankwen church, shares the same Pentecostal faith and, holding a Masters degree, is the highest educated amongst the group. She was also interviewed telephonically and completed the questionnaire. 


\section{Knowing, living and believing: The story of Ruth for single African women}

The women partaking in this study are familiar with the African context revealed in Moremadi's story. They belong to one of the traditional South African Pentecostal churches. Within their church setting, the Christian Bible plays a role not only for providing knowledge, but knowledge of God through the Bible, belief and life, are intricately woven. Thus, when the book of Ruth is accessed, the reader or listener would be looking for answers to specific life's questions. One thus agrees with Nadar (2004) about the way the majority of South African women read the Bible:

They look to the Bible for positive role models, and they use the Bible as a crutch on which to lean in difficult times. In other words, the element of faith is crucial for the way in which South African women interpret Biblical texts. (pp. 67-68)

The observation that all of the 10 women answered the question on particular biblical texts which speak to their lives in the affirmative, points in that direction.

Singlehood, including widowhood, is a steadily growing phenomenon within various communities today. More and more, African churches are experiencing a growing number of single women. Kialu (1998:45) observes: 'Today, celibacy is spreading rapidly and takes its place, whether it is wanted or not, in woman's history in Africa.' However, as it happens with critical issues which affect those on our communities' margins, little attention tends to be given to the needs of this important category of women within our churches. ${ }^{15}$ Their unique set of challenges are either neglected or glossed over, something which might be revealing the patriarchal orientation of our churches' leadership structures. Dick's (2011) remarks are noteworthy:

Christian men do not have this problem because they have many desirable females to choose from to fulfill their need for marriage and parenting. And sometimes men do not understand female sexuality and female instincts. And since men dominate the hierarchy of the church, the rules tend to be insensitive to the needs, aspirations and orientation of women. (p. 1; cf. also Kialu 1998:45 on the lack of laws which protect an unmarried African woman)

Owing to the scarcity of works which take single women's contexts seriously, particularly widows' contexts, be it in biblical scholarship and in our churches amongst others, I have decided to re-read the book of Ruth, this time, informed by some of the experiences of single women. Although I had previously conducted a bible study on Ruth with some of these women, in 2012 we had another opportunity to engage the book. The main questions asked were: as a widow or single woman living in the 21st century, is the story of Ruth in the Old Testament helpful (or not) in your life? If so, why?

15. As an insider to this particular church tradition, as one who learns from the women and sometimes has moments of sharing with them, I have noticed that very little, if anything, is done by biblical scholars regarding single women's hermeneutics. Yet if research particularly pertaining to the sexual needs of single women was to be given the necessary attention, not only would the women benefit a great deal, but so too would the clergy in whose charge the women find themselves. I thus agree with Hofstee (2006:57) regarding primary research that it is important that researcher asks who the likely beneficiaries of such a research would be.
How was the character of Ruth presented in single women's sessions? Which practical ways could be suggested to address sexual challenges encountered by single women in a context of scarce men, where legitimate sexual relations should occur within the context of (heterosexual) marriage? A separate yet related question I ask in this article is: which (legitimate) possibilities for progeny do interested single women have within such contexts?

I now present the narratives of maho a go tšwa dipitšeng [wooden spoons from the pots], women who have the experience of being single. These are the women with whom I fellowship in Mankweng, Polokwane. As previously noted, we engaged the story previously and again recently. The words of West (2006) come to mind here:

For those of us who give priority of place to the African context, however, bracketing either faith or biblical scholarship is irresponsible. Indeed, it is doing our work as biblical scholars in an explicit engagement with our context that integrates and reconstitutes our faith and our scholarship. (p. 317)

Although I engaged with 10 women, space constraints dictate that I focus on the narratives of only five of them; the section on the analysis of the findings below will hopefully provide us with a bigger picture.

\section{Listening to single women's narratives Participant 1}

Participant 1 is a 54-year-old single woman who is comfortable with her single status as she gets space to think soberly. She is also comfortable with her relationship to God but not with the African culture as many issues are forced upon people. Single life enables her to have self-reliance, accepting the reality of not having a helper. The biblical texts which speak directly to her life are Psalms 124 and 127. The book of Ruth still speaks to her today because of Ruth's move to agree to join her mother-in-law. However, she views with distaste the fact that Ruth was given a man in order to bear a child for him. Being aware of examples of levirate marriages in her culture, she thinks that the church could recommend them as a way of addressing all the needs of single women. Although she did not provide any solution for sexual challenges faced by single women, she acknowledges the need for intervention in that regard.

\section{Participant 2}

Participant 2 is a 50 -year-old single woman who has been single for the past 11 years. She would like to have a husband because she believes that it is important for a family to have a man. She is comfortable with her relationship with God because God's care for her is revealed by her being single. As a single woman, she has the advantages such as not having to ask someone if she could get up and pray; that wherever she would like to go, she could just pray and ask God and go. The texts which speak into her life as a single woman are Psalm 91 (God, the Refuge and the Shelter), Isaiah 54:18 (no weapon directed against her will prosper) and Matthew 15:13, on the uprooting of whatever plant not planted by God. The book of Ruth speaks into her life because 
it enables her to hold on to the Lord, to have perseverance and love in the Lord. She is not aware of examples of levirate marriages. She does not think that such marriages could be helpful as a solution to meeting all the needs of single women because the Word of God says that one man is supposed to have one wife. When faced with sexual passions, she seeks assistance from the Holy Spirit. When her flesh 'gets up', she prays and asks God to help her.

\section{Participant 3}

Participant 3 is a 36-year-old woman whose reality of being single set in during 2004. Her single status does not affect her relationship with God. She is comfortable with the status because she has children, the latter are her future. She prefers to be a Christian woman rather than a traditionalist because the African culture has many rules. The advantages of single life are that single women live their own lives, asking no permission from their husbands. The biblical text which speaks to her life is Jeremiah 1 . The book of Ruth does not speak to her because she cannot marry a relative. Regarding solutions to challenges about sex, she feels that single women should talk about sex and share their feelings with one another.

\section{Participant A}

Participant A is a 73-year-old woman who was widowed in 1985. ${ }^{16}$ Her widowhood did not change her attitude towards God. The Lord has been her Shepherd throughout the years. Rather than being a traditional African widow, she prefers to be a Christian one because she can be freed from sicknesses. She finds the book of Ruth helpful as it enables her to hold on to her faith in God. Ruth holding on to her mother-in-law provides a good model of encouragement in her Christian walk. She is aware of examples of levirate marriages and is against the suggestion that the church recommends such as a solution because it is better for a woman to marry her own husband. Regarding the solution to widows' sexual challenges, Participant A believes that the answer is prayer.

\section{Participant C}

Participant $C$ is 39-year-old woman who became a widow in 2004. For her, single women who choose to stay with African traditional culture have a smooth ride because they can easily have a boyfriend who comes and goes. However, Christian single women who know that sex outside of marriage is sin need to practice what they preach. Two texts which speak to her life are Luke 1:37 and the text on a widow who took her last oil and bread to serve God's servant (2 Kings 4:1-7). On the book of Ruth, she remarks: '... but the book does not help' (Participant C, female, 39 years old).

She gives three reasons for her assertion, (1) some widows do not have people like Boaz within their relatives, (2) some have children whereas Ruth did not have children and (3) the book presents a single difficult story as today's widows may

16.For the purposes of differentiation and thus affirming single women in their diversity, participants are numbered differently. The widows are numbered alphabetically, whilst single women in other categories such as those who are divorced and those who never married, are numbered numerically. not have women of Naomi's wisdom. From the sermons and teachings on the book, widows are encouraged not to depart from their in-laws after their husbands' deaths. She is aware of the existence of levirate marriages, though she is quick to note that they do not work. She opines, though hesitatingly, that levirate marriage could be proposed by the church as a way of addressing all the needs of widows, saying: 'Maybe, but women don't want anything with their men. First women disagree with it while men they don't see problem with it' (Participant C, female, 39 years old).

Regarding possible solutions to challenges pertaining to sex, she suggests, (1) masturbating (even though it is dirty), (2) waiting for marriage, (3) marriage across denominations or religions and (4) sex toys.

From my interaction with the women through the Bible study sessions, casual conversations and, in particular, from their responses in the questionnaires, the following three themes emerged, which are discussed below.

\section{Christian women within African culture}

Almost all of the women in this study (except two) are aware of the practice of go kgobelwa monna, literally, to be allocated a man (cf. levirate marriage). The observation that almost all of them, including those entertaining the possibility of remarriage, do not recommend go kgobelwa, that is to be allocated a man (as in the case of a levirate marriage) as a possible solution to addressing all their needs, reveals something of their general distaste for this particular aspect of African culture. Perhaps it also reveals something of missionary and colonial histories. Even so, Participant 1 and Participant C recommended it as a possibility. For some, African culture disempowers women because of 'constraints' and 'rules' imposed on them (cf. Participant 1, Participant 3 and Participant 4). Hardly any of them noted the 'constraints' put on them by the Bible. Only one respondent states:

'... Non-religious because [they] don't [sic] see it [as] a problem to have a boyfriend who will come and visit a single woman or widow and go. [To] religious people everyone knows tha $[s i c]$ is a seen [sin]. We know is [sic] we preach it so we must practice it.'

(Participant C, female, 39 years old)

Whilst specific aspects of African culture are rejected, others seem to be upheld. Ruth appears as a model to most of them because of her decision to continue to stay with her mother-inlaw after her husband's death. Although the proverb 'lebitla la mosadi ke bogadi' ['a married woman's grave is located at her husband's place'] did not come up in our discussions and was only cited by Participant F, the underlying mentality behind the proverb most probably shaped both the sermons received about Ruth (cf. Participant 2, Participant 3 and Participant F) and their own understanding and endorsement of Ruth's faithfulness.

\section{The story of Ruth: Affirming, disaffirming or both?}

In this study, $80 \%$ of the respondents found Ruth's story affirming for several reasons, including Ruth's faithfulness to 
her mother-in-law and her perseverance. Ruth's faithfulness, vis-à-vis Orpah, was confirmed in the discussions by Participant A. Only two respondents were forthright about their affirmation by Ruth's move to go with Naomi (cf. Participant 1 and Participant D). The widows seem to appreciate Ruth's decision not to divorce the grave. Maleke Kondemo (pers. comm., 23 May 2012) reveals something more or less similar in the context of the Democratic Republic of Congo:

'Mostly, Ruth is regarded as model of young women, those who are still strong and able to bear children. She is a model of hope, hope to survive without a husband and hope of finding a good husband'.

Also, Ruth's perseverance and faithfulness serve as model for perseverance in their Christian walk (cf. Participant A, Participant E, Participant F and Participant 2). Such faithfulness to God is interestingly missing from the story, for example, the women did not support Ruth's visit to the threshing floor! Ruth was not always loyal to her mother-in-law's exhortations (Rt 1:16-17; 3:9). The teachings received on the story, exhorts single women not to leave their in-laws (cf. Participant B, Participant C, Participant D and Participant F). An African Christian widow who does not leave her in-laws after her husband's death also reveals her commitment to God (cf. from conversation with Participant C and implicitly with Participant F). It is thus easy to see how the women could be 'trapped between two canons' (cf. Masenya [ngwan'a Mphahlele] 2003): the Bible and the African culture. What is presented as God's will, is pretty much clad in African attire and the latter may not always accord with the season in which it is clad. In certain instances, it might even be dangerous to do.

In this study, $20 \%$ of the respondents do not find the book of Ruth affirming. The youngest respondent (Participant 3) is clear that the story does not speak to her because she does not want to marry a relative. The youngest widow holds a similar view of not wishing to be married to someone she does not love. The book of Ruth does not speak to Participant 4 , as it presents the story of: '.. a woman who started out single. But the story culminates with her prayers being answered through a man: marriage, love, child and provision' (Participant 4, female, age 46).

A more elaborate response is given by Participant $\mathrm{C}$, a 39-year-old widow who says: '. .. but the book does not help'. She argues that the experiences of present-day widows are different from those of the two widows in the book and provides reasons why she finds the book unhelpful.

\section{Embracing the sexuality of single women}

From Moremadi's narrative, it became clear that at the core of the Naomi-Ruth narrative is the perpetuation of the male line, be that of Elimelech, Mahlon and/or Boaz (cf. Rowley 1947:97-99). Hence, what was to be celebrated more in marriage seems to have been a woman's role as a mother than as a wife. A marital couple's sexual life did not seem to have had a place in the biblical narrators' minds. We may recall the narrator's preoccupation more with babies and the perpetuation of the male lineage in the preceding narrative (cf. Rt 4). ${ }^{17}$ However, Mbuy Beya (1989b) notes:

In itself, sexuality is both noble and good. It is part of God's plan for mankind [sic]. Gen1:27 tells about God's creation of man and woman in His image. Besides, in Gen 1:26-28 the two of them are instructed to dominate the earth and to fill it together, according to each one's identity. Similarly, Gen 2 and 3 tell us of the reciprocal responsibilities of husband and wife in the plan of God for humanity. (p. 56)

Sex is one of those God-given 'gifts' which have made or broken people through the years. Where and when and with whom it is supposed to happen, has been, and continues to be, the subject of discussions by religious authorities and the laity alike. What has not been communicated so far about the women in the focus group is that all of them have children. It also became clear from the narrative of Participant 3 that the children are her future. Furthermore, from informal and previous discussions with some of them, it was revealed that one of the reasons why they are not keen on (quick) remarriage is children. Unlike in Moremadi's narrative, where note was made about the obsession with babies, there was no need to engage the widows' reproductive capacities in our session. Such an engagement happened though, in a previous Bible study, in which it became clear that one of the reasons for a younger single woman to marry was also to have children. The question is: what if a Boaz may eventually not show up (as it usually happens), whilst a woman's maternal instincts may dictate otherwise? Dick's (2011) words come to mind here:

Indeed, many single Christian women desire to have a child while maintaining their Christian commitment. However, there are not enough men in the church when it is considered that, generally speaking, there are two women to every man. Furthermore, in many churches there is a prohibition against women marrying men who are not Christians or churchgoers. Therefore, the options for a female Christian are limited. Some females with a desire to fulfil their maternal instincts, and noticing that the prospects of getting married are slim, will have a child outside of marriage and leave the church for a while and then return after a hiatus. This action is still frowned on as engaging in a sexual immoral act to conceive. Some will adopt children. (p. 1)

The widows in the focus group were mothers and were once wives. Although they have children, they have no one with whom they can enjoy a conjugal bed. Sex, both within their culture and the church tradition, can only happen within marriage. The church constituency hardly has any bachelors or unmarried widowers. How may single women's sexuality be fully celebrated under such circumstances? In the case

17.The observation though that at the threshing floor, Ruth might have been the one to make sexual advances to Boaz is not without its own challenges. Firstly, the language in which the incident of Ruth's visit to the threshing floor is cast, is full of ambiguities. The reader is thus not always sure if there was indeed a sexual encounter between Ruth and Boaz. Other questions may be asked: if Ruth was not a Moabite, that is, if Ruth was an insider to the traditions of Israel in terms of ethnicity, would Naomi, as well as the Judahite narrator, have presented such a problematic scene? Could it be that Ruth is being sexualised because of the problematic history between the Moabites and the Israelites? Gafney (2010:251) problematic history between the Moabites and the Israelites? Gafney (2010:251) reasons that, "The very name, "Moab," literally "from $[m y]$ father", evokes the alleged incestuous and therefore despicable nature of all Moabites according to the Israelite account of their origins in the Genesis 19 account of Lot and his daughters. As a result, Moabites, particularly Moabite women, are highly sexualized in the scriptures of Israel, as are many contemporary African women readers of those same scriptures.' (Africana women: African women both on African the continent and in the African diaspora). 
of younger widows whose spouses died without children, could there be any way out?

In this study, $20 \%$ of the women supported the idea that levirate marriage could serve as a solution to the meeting of all their needs. At least from one respondent, it can be speculated that such a possibility is envisaged in the context of agreement by all the parties concerned.

Also, from the study, it emerged that $50 \%$ of the respondents pointed to prayer as a solution to sexual challenges; half of these are explicit about it, whilst the other half are implicit, as in the need to flee from earthly things (cf. Participant D) and the need to approach the issue of sex with patience (Participant E). The youngest single woman (Participant 3) suggests that there be talk about sex amongst women. Another 20\% acknowledged the existence of sexual challenges but could not suggest practical solutions. It would not be an exaggeration to argue that at the back of their minds, the latter category would also point to prayer as a solution, to persevere until a Boaz shows up (cf. Participant 2 and Participant E). Then, $30 \%$ of the women provided examples of what might prove helpful: sex toys, masturbation, awaiting marriage and the need for the church to expand the sphere of choice of potential marriage partners. Given the nature of the church tradition, the nature of theology and biblical studies as they were received since colonial and apartheid eras and the scarcity of attention given to single women's issues, are we surprised that a larger percentage would 'spiritualise' a solution to a biological issue such as a sex drive? Are we puzzled that $20 \%$ of the women would acknowledge that there is a challenge and yet not be able to suggest possible solutions? Indeed, we have taught, and continue to be taught, that the full gospel pertains to the conversion of the soul. The soul and not the body with its evil (sexual?) desires needs to be nurtured. In the process, we have left, and continue to leave, some of the needs of this important, growing constituency unattended. Even if we did, given the patriarchal nature of our contexts, the solutions are not always women-friendly. The words of Nora, the main protagonist in the novel, Reverend Mother come to mind here:

Most of the battles in the church for the last half a century have to do with women and their bodies, whether it is birth control or abortion or sex, or the matter of having children. It is always about us and our bodies, what we can do or cannot do. And it is always men who are telling us what is right from what is wrong as to what to do with our bodies, and our own sexuality. (Henry 2011:140)

\section{Conclusion}

As we conclude, it has hopefully become clear that for certain Bible readers, knowledge, faith and life are intricately woven. The emphasis on knowledge only, for example, an emphasis which continues to be the pride of academia even when it does not touch an inch of our communities' lives, cannot be sufficient (cf. West 2006:317). Such a detached stance has the capacity to leave many critical questions unanswered, questions such as: what if a Boaz does not eventually show up for those widows and other single women who entertain the possibility of re-marriage? What about the women who are not interested in a Boaz but would like to celebrate their sexuality to the fullest? What about childless widows who still entertain the possibility of having children, with or without a Boaz? What about those widows who, whilst they were by nature, same-gender loving, but as a result of 'the hetero-patriarchy-as-norm' context which produced them, had to marry heterosexually and, only now, no longer wish to betray their sexual orientation? Could such for example, be allowed to be affirmed by affectionate female relationships within some of our African contexts, compare the metsoalle and mummy-baby dyads of Lesotho (Gay, in Kendall 1998) and the Azande women of Sudan (Evans-Pritchard 1970)? Elsewhere, Masenya (ngwan'a Mphahlele) (2012) remarks:

Women such as those within the metsoalle and the mummybaby dyads, even within their Christian faith confession, seem to have not been embarrassed by their love and affection for fellow-women. Their (the societal) firm conviction that sex can only happen when there is a koai (penis) seems to keep them in tact regarding their smooth relationship with the church and the broader society. (p. 60)

From the findings of this study, it is no wonder that most of the relationship features in Alpert's (1996) lesbian reading of the Naomi-Ruth story would make perfect sense within such relationships. An important question to be posed mainly to the ecclesial community, and particularly those who are vested with the power to interpret the Word, who seldom offer concrete alternative solutions regarding the sexual needs of single women is: could the metsoalle relationships, and their affirmation by Alpert's (1996:91-96) reading of the Naomi-Ruth story, serve as model for many single women to imitate without condemnation?

Regarding a few practical solutions proposed by a meagre percentage of the women above, could the religious establishment endorse such with ease? Kialu (1998:45) cannot persuade one to be optimistic when she refers to masturbation amongst unmarried African women as one of the forms of sexual deviations. Regarding procreation without a Boaz, could the church affirm the proposition by Henry (2011:212) that present-day technology needs to be affirmed as a way of resolving some of the challenges faced by single women in our churches? In his intriguing, rich novel entitled, Reverend Mother, Reverend Eron Henry, a Jamaican Baptist minister, presents a moving story of an ordained single female minister who, against all odds, chose to address her maternal instinct by falling pregnant without a Boaz. Elsewhere Nora, the Reverend Mother, responds to Janet her friend:

Man? The issue is not man. It's love, it's family, it's wholeness, it's ... companionship. It's having someone to call your own. I don't want to grow old and be all alone. (Henry 2011:115)

Nora who eventually gets stripped of her ministerial credentials gave birth to a baby boy within a Boaz-less family context. Could our churches, unlike the Jamaican church to which Nora belonged, endorse such a move? 
Our commitment to addressing the needs of the neglected members of our communities such as single women, may enable the academy and the church alike to be as the go'el hayil, the go'el of substance, as Oduyoye (2004:154) reminds us that: it enhances, rather than diminishes the power of the powerful when they become advocates for justice and healing. As each of us become the go'el of substance, perhaps the story of Ruth in the Hebrew Bible might be found by these women to be indeed knowledge-worthy, faith-nurturing and life-enhancing.

\section{Acknowledgements Competing interests}

The author declares that she has no financial or personal relationship(s) that may have inappropriately influenced her in writing this article.

\section{References}

Alpert, R., 1996, 'Finding our past: A lesbian reading of the Book of Ruth', in J.A. Kates \& G.T. Reimer (eds.), Reading Ruth: Contemporary women reclaim a sacred story, pp. 91-96, Ballantine Books, New York.

Chandler, J., 1991, Women without husbands: An exploration of the margins of marriage, MacMillan, London.

Cibalonza, F., 1998, 'The evolution of the African woman's sexuality', in M.B. MbuyBeya (ed.), Woman, who are you? A challenge, pp. 38-40, Paulines Publications Africa, Nairobi.

Dick, D., 2011, Story of 'Reverend Mother', viewed 17 May 2012, from http:// jamaicagleaner.com/gleaner/20110324/cleisure/cleisure2.htm

Dube, M.W., 2001, 'Divining Ruth for international relations', in M.W. Dube (ed.), Other ways of reading: African women and the Bible, pp. 179-195, SBL, Atlanta.

Evans-Pritchard, E.E., 1970, 'Sexual inversion among the Azande', American Anthropologist 72, 1428-1434. http://dx.doi.org/10.1525/aa.1970.72.6.02a00170

Gafney, W., 2010, 'Ruth', in H. Page et al. (eds.), The Africana Bible: Reading Israel's scriptures from Africa and the African diaspora, pp. 249-254, Fortress, Minneapolis.

Henry, E., 2011, Reverend Mother, Eron Henry, Washington, DC.

Hofstee, E., 2006, Constructing a good dissertation: A pratical guide to finishing a Master's, MBA or PhD on schedule, Epe, Sandton.
Kanyoro, M.R.A., 2002, Introducing feminist cultural hermeneutics. An African perspective, Sheffield Academic Press, New York.

Kendall, 1998, "When a woman loves a woman" in Lesotho: Love, sex, and the (Western) construction of homophobia', in S.O. Murray \& W. Roscoe (eds.), Boywives and female husbands: Studies of African homosexualities, pp. 223-241, New York, St Martin's Press.

Kialu, T.G., 1998, 'The African woman and celibacy', in M.B. Mbuy-Beya (ed.), Woman, who are you? A challenge, pp. 45-49, Paulines Publications Africa, Nairobi.

Kondemo, M.M., 2012, single women in the DRC, email, 23 May, malekkm@unisa. ac.za

Masenya (ngwan’a Mphahlele), M., 1996, 'Ngwetši (Bride): Reading the Naomi-Ruth story through African eyes', paper presented at the Congress of the Old Testament Society of South Africa, 02-04 September, Stellenbosch.

Masenya (ngwan'a Mphahlele), M., 2003, 'Trapped between two canons: AfricanSouth African Christian women in the HIV/AIDS era', in I. Phiri et al. (eds.), HIV/AIDS, African women and faith communities, pp. 113-127, Cluster, Pietermaritzburg.

Masenya (ngwan'a Mphahlele), M., 2004, 'Teaching Western-oriented Old Testament studies to African students? An exercise in wisdom or in folly?', Old Testament Essays 17(3), 455-469.

Masenya (ngwan'a Mphahlele), M., 2012, 'Rebecca Alpert's lesbian reading of the Book of Ruth within the Metsoalle context of Lesotho', Journal of Gender and Religion in Africa 18(1), 43-62.

Mbuy-Beya, M.B., 1989a, 'The African woman and prostitution', in M.B. Mbuy-Beya (ed.), Woman, who are you? A challenge, pp. 49-55, Paulines Publications Africa, Nairobi.

Mbuy-Beya, M.B., 1989b, 'Sexuality and religion', in M.B. Mbuy-Beya (ed.), Woman, who are you? A challenge, pp. 55-60, Paulines Publications Africa, Nairobi.

Moyo, F.L., 2005, 'The red beads and white beads: Malawian women's sexual empowerment in the HIV \& AIDS era', Journal of Constructive Theology 11(1), 53-66.

Nadar, S., 2004, 'Subverting gender and ethnic assumptions in biblical narrative: Exploring the narrative voice of Ruth', Journal of Constructive Theology 6(2), 67-83.

Nzimande, M.K., 2005, 'Postcolonial biblical interpretation in post-apartheid South Africa: The in the Hebrew Bible in the light of Queen Jezebel and the Queen Mother of Lemuel', unpublished PhD dissertation, Brite Divinity School, Texas Christian University, USA.

Oduyoye, M.A., 2004, People of faith and the challenge of HIV/AIDS, Sefer, Ibadan.

Phiri, I.A., 2006, 'Ruth', in T. Adeyemo (ed), Africa Bible commentary, pp. 319-324, World Alive Publishers, Nairobi.

Rowley, H.H., 1947, 'The marriage of Ruth', Harvard Theological Review XL(2), 77-99. http://dx.doi.org/10.1017/S0017816000026298

Sakenveld, K.D., 1999, Ruth: Interpretation. A Bible commentary for teaching and preaching, John Knox, Louisville.

Tull, P.K., 2003, Esther and Ruth, Westminster John Knox Press, Louisville. PMCid:PMC2594649

West, G.O., 2006, 'The vocation of an African biblical scholar on the margins of biblical scholarship', Old Testament Essays 19(1), 307-336. 